\title{
Forest and Rangeland Staff' Training Needs in Iraqi Kurdistan Region and Correlation to Personal and Occupational Factors
}

\author{
Abid Ali Hasan Al-Doski, Mijda Bahzad Mohammad Alsinayi ${ }^{1}$
}

\begin{abstract}
The main objective of the study is to assess the training needs of the forest and rangeland staff in the Iraqi Kurdistan Region (IKR). The procedure is to identify the training needs in all forestry aspects: (forest development, forest protection, forest range management, agro-forestry, environment, tourism and recreation and forestry extension), determining the relationship between the respondents training needs and some of their personal and occupational features, explore the problems and obstacles in the protection and development of forests in IKR; consider the respondents' suggestions for developing and improving Iraqi Kurdistan Region forests. The research samples included 132 employees representing about $77.19 \%$ of the research population. The data was collected through questionnaires and personal interviews. The following are the main findings of the study:

The results show that $49 \%$ of the respondents need extensive training in all the studied forestry disciplines and that there is a significant correlation between the need for training and each of the independent variables (age, career service and origin). Besides, the three stated variables altogether explain about $33.7 \%$ of the variance in the IKR forest and rangeland staff's' need for training. In light of the study findings, the recommendations was developing training plans and programs for the Iraqi Kurdistan region forest and rangeland staff in the prioritized topics the respondents desire to be trained in.
\end{abstract}

\section{INTRODUCTION}

Forests are not mere vast green cover; rather they have economic, social, industrial and recreational significance. They also prevent soil degradation and erosion; protect water springs; maintain the stability of mountains; reduce the effects of global warming through the green mantle, which absorbs dioxide carbon; save biodiversity from extinction; provide energy and raw materials. Throughout ages forests played a crucial cultural and historical role as they were inhabited by humans since ancient times. Despite their great importance, forests are damaged and abused greatly. The widespread loss of forests is one of the factors that threaten environment and humans most. $15 \%$ of the world's forests disappeared between 19501980 as a result of humans' transgression, mostly in North Africa and the Middle East (Chizari et al, 1999). The population growth, increased demand for wood

College of Agriculture and Forestry-University of Dohuk

Kurdistan Region_Iraq

Received Julyl 29, 2015, Accepted September 20, 2015 products and illegal logging has degraded forests even more (FAO, 2009).

Historical evidence and field observations indicate that the forestlands in Iraqi Kurdistan were covered with vegetation, such as trees and shrubs of good qualities and high economic values. They include oaks, pines, sumacs and others whose wood, seeds and fruits are used. However, they have lost their good qualities; their economic value has decreased as a result of continued misuse (Abdullah, 1980). There are several reasons why the vegetation in Kurdistan Region and Iraq, particularly forests, has deteriorated, some natural and related to human misbehavior towards forests and ignorance about their significance.

The principal causes can be summarized as follows; Natural Causes, Iraq (including Kurdistan) is located in a zone of transition in terms of climate and other environmental conditions, thus having a critical climate where a long dry season and hot weather are the major challenges faced by the forests in the region.

Secondly Man-made Causes, overcutting trees and haphazard logging of extended woodlands ensue from pressures of population density and multitudinous uses of timber. Fires, deliberate or otherwise, still gripping most of Iraqi Kurdistan natural forests, cause considerable woodland removal. Concerned technical departments lack modern programs and equipment to fight wildfires. Environmental problems involve burning of tree seeds. Wooded areas have been devastated by inability to reforest after forest fires, tree diseases, harmful plant insects, environmental unawareness, under reckoning of such vital and renewable resources have had the vegetation cover degenerate. Therefore, it is necessary to develop effective programs speedily to improve the status of forests, increase the forested areas and existing species, protect the remaining forests from destruction and arson, and punish the arsonists so that they should recover and do their envisaged duties.

Forest protection against various challenges and degradation factors and increase of their areas need intensive extension services at all social levels and strata as well. Likewise, awareness should be developed within decision-makers about the value of forests to gain their trust and support in the protection and 
expansion of forests. The first step in designing effective and integrated programs is to have efficient, qualified and well-trained personnel who are able to convey extension messages, educate the locals about forest significance and safeguarding and engage them in programs during all the stages. Human capacity building and availability of qualified personnel with professional competences and expertise are among the most relevant factors in fulfilling the strategic objectives of development plans in various sectors including forestry. There is scarcity of researches in the area of forest and rangeland staff training needs in Kurdistan and Iraq. Therefore, this study has been conducted as an attempt to answer the following questions: What are the IKR forest and rangeland staff training needs? Do these needs vary according to personal and occupational qualities? What are the problems and obstacles of forest protection and development? What are the forest and rangeland staff's suggestions for the protection and development of forests?

Hence the value of this study is manifested by answering these questions. It will help in developing and planning effective programs aimed at building the capacities and skills of IKR forest and rangeland employees. Besides, it will assist officials at all levels to frame policies that can enhance the potentials of forestry and rangeland departments in IKR, create encouraging conditions to work and foster the coordination spirit at all levels with other concerned institutions. Appropriate programs and policies can be formulated for protecting the existing forests and maintaining their sustainability, utilizing them, in addition to increasing their areas. That will promote the public perception of the significance and benefits of forests, raise citizens' awareness and understanding of the reverse implications of deforestation, forest degradation and encourage the sensible and controlled use of these invaluable resources.

\section{Objectives}

This study mainly aimed at identifying the training needs of forest and rangeland staffs in the governorates of Duhok, Erbil and Sulaimania, the specific objectives were:

1. To identify the training needs of the forest and rangeland staff in the governorates of Duhok, Erbil and Sulaimani in the following disciplines: (forest development, forest protection, forest range management, agro-forestry, environment, tourism and recreation and forestry extension).

2. To determine the relationship between the forest and rangeland staff training needs and some of their personal and occupational variables.
3. To determine the relationship between the forest and rangeland staff training needs and the total personal and occupational characteristics.

4. To determine the perceptions of forestry and rang department Staff in the targeted area regarding effective factors in deforestation of forests

\section{Hypotheses}

There is no significant correlation between the IKR forest and rangeland staff training needs as a dependent variable and each of the following independent variables: Age, sex, origin, educational qualifications, academic specialization, nature of work, work climate, desire to continue forestry work, career service, participation in trainings, trend towards forestry.)

1. There is no significant correlation between the IKR forest and rangeland staff training needs as a dependent variable and the independent variables altogether. The two hypotheses were tested in Null hypotheses

\section{Methodology}

\section{Population and Sample}

The research population is composed of all the 171 forests and rangelands employees in the 3 governorates (Duhok, Erbil and Sulaimani). The data was collected from 132 employees representing about $77.19 \%$ of the research population, Face and content validity of the instrument was established by the panel of experts, their suggestions were incorporated in the final version of the instrument.

\section{Research design and Data analysis}

To analyze the objectives of this study a questionnaire of four parts was designed as follows: The first includes a set of questions to recognize personal and functional characteristics of the respondents. The second includes a scale to measure the dependent variable, Consist of 91 items distributed among 7 domains (Forest Development; Forests Conservation; Rangeland Management; Agroforestry; Environment; Tourism; and Forestry extension). The third includes a set of questions to determine the main constraints and problems of forests as perceived by the targeted respondents. The fourth includes a set of questions to determine the key suggestions for the development and conservation of forests in the Kurdistan region of Iraq.

Borich developed equation was used to determine the training need in each item as follows:

$\operatorname{Tn}=([\mathrm{I}-\mathrm{K}) * \mathrm{I}]+[(\mathrm{I}-0) * \mathrm{I}]) / 2$

Where: -

$\mathrm{Tn}=$ Training need in each point. 
$\mathrm{I}=$ Importance of item from the respondent's perspective.

$\mathrm{K}=$ Degree of information the respondent has on the point.

$\mathrm{O}=$ Degree of opportunity the respondent uses the point.

Based on this equation, the theoretical degree of the need in each item ranges between +20 and -4 .

\section{RESULTS AND DISCUSSION}

Identifying the training needs of the forest and rangeland staff in the governorates of Duhok, Erbil and Sulaimani: In the following disciplines: (forest development, forest protection, forest range management, agro-forestry, environment, tourism and recreation and forestry extension).

The respondents were divided into 3 categories according to the degree of their training needs: First category included the respondents whose degree of training need was (392) or less, i.e. (18.939\%) of the total respondents. Second category included respondents whose degree of training needs ranged between (393 and 598) degree (31.818\%); third category of those with (599) or more degrees $(49.242 \%)$. The arithmetic mean was (629.096) and standard deviation (298.242).

The data in Table 1 indicate that the most majority of the respondents in the 3 governorates of Duhok, Erbil and Sulaimani belonged to the category 'Great Training Need'. May be this is due to the fact that the largest percentage $(78.030 \%)$ of respondents were not forestry specialists. It reflects the importance of planning and implementing training programs for these employees to meet their work requirements and develop their capacity to carry out the required tasks.

Table 1. Shows Distribution of Forestry and Rangelands Respondent Staff according to the Training Needs

\begin{tabular}{|c|c|c|c|c|c|c|c|}
\hline No. & Governorate & 392 \& Less & $\%$ & 393-598 & $\%$ & 598 \& More & $\%$ \\
\hline 1 & Duhok & 8 & 6.061 & 11 & 8.333 & 12 & 9.091 \\
\hline 2 & Erbil & 10 & 7.576 & 15 & 11.364 & 23 & 17.424 \\
\hline 3 & Sulaimani & 7 & 5.303 & 16 & 12.121 & 30 & 22.727 \\
\hline & Total & 25 & 18.939 & 42 & 31.818 & 65 & 49.242 \\
\hline
\end{tabular}

Table 2. Shows Order of Forestry Disciplines according to Forestry and Rangelands Staff Training Needs

\begin{tabular}{lcc}
\hline \multicolumn{1}{c}{ Forestry Disciplines } & Training Need Mean & Rank \\
\hline Rangeland Management & 987.778 & 1 \\
\hline Agroforestry & 905.778 & 2 \\
\hline Environment & 866.318 & 3 \\
\hline Tourism & 763.458 & 4 \\
\hline Forestry Extension & 550.964 & 5 \\
\hline Forest Protection & 484.278 & 6 \\
\hline
\end{tabular}

Determining degree of forestry and rangelands personnel training needs in Kurdistan Region of Iraq in all of the studied forestry disciplines.

The results of Table 2 show that the Forestry and Rangelands staff in the Kurdistan region of Iraq lack inservice training in most of the studied disciplines. This is largely due to the rareness or lack of in-service training opportunities. (71.970\%) of them pointed out that they did not participate in any in-service training; therefore the concerned departments should work on improving the in-service training for the respondent staff.

The table (2) indicates too that the Rangeland Management is in the forefront of the studied areas in terms of training need with an arithmetic mean of (987.778). The reason for this is that ranges have natural economic significance in the development of animal wealth, being as a source of feed and food security needs of the country and for its role in the soil, water and wildlife conservation. The need for in-service training in agroforestry came in the second place with a mean of (905.778). This is because agroforestry significantly alleviate pressure on forests by reducing conversion to farmlands; it protects soil from erosion and increases its ability to retain water; in addition to its economic benefits through improving and diversifying production.

The need for training in the forest conservation and forest development disciplines ranked sixth and seventh, despite the significance of both areas for forests in general. Mostly this is because the respondent staff grew experienced in the two domains through work and job practice. 
Determining Correlation between Degree of Forestry and Rangelands Staff Training Needs in the KR of Iraq in Forestry Domains and Each Independent Variable:

1- Age

Table 3 shows that $(33.333 \%)$ of the respondents belong to the age group (35 Yrs. or Less); $(27.273 \%$ ) of them belong to (36-49 Yrs.); and (39.394\%) to age group (49 or More). That is, the majority of respondents have their ages between 'Young' and 'Middle-aged' categories, making it fairly possible to take advantage of their potentials.

To find a correlation between the respondents' training needs degree and Age variable, the Simple Correlation Coefficient was used $(r=0.220)$, which is a significant value at the probability level $(0.05)$, i.e. there is a positive correlation between the two variables, reject the null hypothesis in favor of the alternative hypothesis. As noted by Al-Abassi (1998) this result can be interpreted by saying that the older an individual gets the more mature his/her character becomes and begins to understand work more clearly. This leads to an increased need for training in his/her field of work. The result corresponds with Faham et al (2008) and Ghadheeb and Doaa (2013) studies.

\section{2- Gender}

As shown in Table 4, the proportion of males is $84.8 \%$ while females $15.2 \%$ to the total respondent staff.

To find the correlation between the degree of the Forestry and Rangelands staff training needs and Gender variable, Chi-square was used with a value $=0.375$, which is insignificant, i.e. there is no correlation between the two variables, which implies that the null hypothesis had been proven true. May be the reason is the all respondents personnel need training irrespective of their gender whether they are females or males. This result is consistent with the Al-Abassi's (2004) study.

\section{3- Background}

As shown in Table 5, the respondents with rural background were $28.788 \%$, while the percentage of respondents with urban background was $71.212 \%$.

To find a correlation between the degree of respondent staff's training needs and Background variable, Chi-square was used. Its value was (6.810), which is significant at the probability level $(0.05)$, i.e. there is correlation between the two variables, reject the null hypothesis in favor of the alternative hypothesis.

Table 3. Shows Distribution of Respondents according to Age

\begin{tabular}{|c|c|c|c|c|c|c|c|}
\hline \multirow[t]{2}{*}{ No. } & \multirow{2}{*}{ Governorate } & \multicolumn{5}{|c|}{ Age Group } & \multirow[t]{2}{*}{$\%$} \\
\hline & & 35 Yrs. or Less & $\%$ & 36-49 Yrs. & $\%$ & 50 Yrs. or More & \\
\hline 1 & Duhok & 13 & 9.848 & 10 & 7.576 & 8 & 6.061 \\
\hline 2 & Erbil & 9 & 6.818 & 18 & 13.636 & 21 & 15.909 \\
\hline 3 & Sulaimani & 22 & 16.667 & 8 & 6.061 & 23 & 17.424 \\
\hline Total & & 44 & 33.333 & 36 & 27.273 & 52 & 39.349 \\
\hline
\end{tabular}

Table 4. Shows Distribution of Respondents according to Gender

\begin{tabular}{|c|c|c|c|c|c|c|}
\hline \multirow[t]{2}{*}{ No. } & \multirow{2}{*}{ Governorate } & \multicolumn{4}{|c|}{ Gender } & \multirow[t]{2}{*}{$\chi^{2}$} \\
\hline & & Males & $\%$ & Females & $\%$ & \\
\hline 1 & Duhok & 27 & 20.455 & 4 & 3.030 & \multirow{4}{*}{0.375} \\
\hline 2 & Erbil & 43 & 32.576 & 5 & 3.788 & \\
\hline 3 & Sulaimani & 42 & 31.818 & 11 & 8.333 & \\
\hline & Total & 112 & 84.8 & 20 & 15.152 & \\
\hline
\end{tabular}

Table 5. Shows Distribution of Respondents according to Background

\begin{tabular}{|c|c|c|c|c|c|c|}
\hline \multirow[t]{2}{*}{ No. } & \multirow{2}{*}{ Governorate } & \multicolumn{4}{|c|}{ Background } & \multirow[t]{2}{*}{$\chi^{2}$} \\
\hline & & Rural & $\%$ & Urban & $\%$ & \\
\hline 1 & Duhok & 13 & 9.848 & 18 & 13.636 & \multirow{4}{*}{$6.810^{*}$} \\
\hline 2 & Erbil & 13 & 9.848 & 35 & 26.515 & \\
\hline \multirow[t]{2}{*}{3} & Sulaimani & 12 & 9.091 & 41 & 31.061 & \\
\hline & Total & 38 & 28.788 & 94 & 71.212 & \\
\hline
\end{tabular}


This is maybe due to the fact that the personnel with rural background are more familiar with and sensitive to the problems faced by forests near to which they dwell. This result is in line with the studies of Al-Ma'moori (1995) Al-Abassi (1998) and Al-Shidaydah (1999).

\section{4- Education qualifications}

Table 6 shows that the respondents who have preparatory certificates make up $(25 \%)$, graduates of Agricultural Institutes (11.364)\%, Colleges of Agriculture (62.121\%), and postgraduates (1.515\%) of the total respondents. It is clear from the table too that the largest proportion of workers in the Forestry sector from the 3 governorates of Duhok, Erbil and Sulaimani are Colleges of Agriculture graduates. This can be a good indicator to be used in promoting and upgrading programmes for forest restoration and development.

To find the relationship between the degree of the respondent staff training needs and Academic Qualifications variable, the Simple Correlation Coefficient (-0.036) was used, which is an insignificant value. That is, there is no correlation between the two variables, which implies that the null hypothesis had been proven true. perhaps because all the respondents need training regardless of their educational qualifications since there are few in-service training opportunities as pointed out by the respondents in Table 8. This result corresponds with the studies of Oglah (2010) and Al-Taiy (2012).

\section{5- Specialization}

As seen in Table 7, the percentage of respondents who specialize in Forestry is $(21.212 \%)$ and nonspecialists $(78.788 \%)$. It follows from the table that the vast majority of the respondents are not Forestry specialists, which reflects the extent of their need for on-the-job training to acquire the minimum information needed for doing their assignments.

To find the correlation between the degree of the respondent staff training needs and Specialization variable, Chi-square was used with a value $(0.376)$ that is insignificant. This means there is no correlation between the two variables, which implies that the null hypothesis had been proven true. perhaps for most of the respondents are not Forestry specialists though it is preferable to have specialized foresters. The result agrees with the study of Al-Abassi et al. (2005).

\section{6- Experience}

Table 8 illustrates that the proportion of Short experience respondents is $(58.333 \%)$, Medium experience (15.152\%), and Long experience (26.515\%) of the overall respondents. We conclude from the same table that the majority of respondents belong to the Short experience category, perhaps because they are newly appointed to job.

To find the relationship between the degree of respondents training needs and experience variable, the Simple Correlation Coefficient was used, with a value of $(0.182)$, which is a significant value. That is, there is no correlation between the two variables, reject the null hypothesis in favor of the alternative hypothesis. possibly because the longer experience a respondent has in this domain the greater his/her need for training will be to gain good experience and raise his/her functional competence.

Table 6. Shows Distribution of Respondents according to Educational Qualifications

\begin{tabular}{|c|c|c|c|c|c|c|c|c|c|}
\hline \multirow[t]{2}{*}{ No. } & \multirow[b]{2}{*}{ Governorate } & \multicolumn{8}{|c|}{ Educational Qualifications } \\
\hline & & $\begin{array}{l}\text { Agricultural } \\
\text { Prep School }\end{array}$ & $\%$ & $\begin{array}{c}\text { Agricultural } \\
\text { Institute }\end{array}$ & $\%$ & $\begin{array}{c}\text { College of } \\
\text { Agriculture }\end{array}$ & $\%$ & $\begin{array}{c}\text { Postgraduate } \\
\text { Degree }\end{array}$ & $\%$ \\
\hline 1 & Duhok & 5 & 3.788 & 2 & 1.515 & 24 & 18.182 & - & 00 \\
\hline 2 & Erbil & 16 & 12.121 & 7 & 5.303 & 23 & 17.242 & 2 & 1.515 \\
\hline 3 & Sulaimani & 12 & 9.091 & 6 & 4.545 & 35 & 26.515 & - & 00 \\
\hline & Total & 33 & 25 & 15 & 11.364 & 82 & 62.121 & 2 & 1.515 \\
\hline \multicolumn{10}{|c|}{$\mathrm{r}=-0.036$} \\
\hline \multirow{2}{*}{$\frac{\text { Iable }}{\text { No. }}$} & \multirow{2}{*}{\multicolumn{2}{|c|}{ Governorate }} & & Specis & sation & & & \multirow{2}{*}{\multicolumn{2}{|c|}{$\chi^{2}$}} \\
\hline & & & Forester & $\%$ & Non & forester & $\%$ & & \\
\hline 1 & Duhok & & 17 & 12.879 & & 13 & 9.848 & \multirow{3}{*}{\multicolumn{2}{|c|}{0.376}} \\
\hline 2 & Erbil & & 3 & 2.273 & & 45 & 34.091 & & \\
\hline 3 & Sulaimani & & 8 & 6.061 & & 46 & 34.848 & & \\
\hline
\end{tabular}


$\begin{array}{lllll}\text { Total } & 28 & 21.212 & 104 & 78.788\end{array}$

Table 8. Shows Distribution of Respondents according to work experience

\begin{tabular}{|c|c|c|c|c|c|c|c|c|}
\hline \multirow[t]{2}{*}{ No. } & \multirow[b]{2}{*}{ Governorate } & \multicolumn{6}{|c|}{ Tenure } & \multirow[b]{2}{*}{$\mathbf{r}$} \\
\hline & & $\begin{array}{l}15 \text { Yrs. } \\
\text { or Less }\end{array}$ & $\%$ & $\begin{array}{c}16-26 \\
\text { Yrs. }\end{array}$ & $\%$ & $\begin{array}{c}27 \text { Yrs. or } \\
\text { More }\end{array}$ & $\%$ & \\
\hline 1 & Duhok & 24 & 18.182 & 2 & 1.515 & 5 & 3.788 & \multirow{4}{*}{$0.182^{*}$} \\
\hline 2 & Erbil & 25 & 18.939 & 10 & 7.576 & 13 & 9.848 & \\
\hline 3 & Sulaimani & 28 & 21.212 & 8 & 6.061 & 17 & 12.879 & \\
\hline \multirow{2}{*}{\multicolumn{3}{|c|}{$\mathrm{Sd}=11.807$}} & 58.333 & 20 & 15.152 & 35 & 26.515 & \\
\hline & & & & & \multicolumn{4}{|c|}{$\mathrm{X}^{-}=15.962$} \\
\hline
\end{tabular}

Table 9. Shows Distribution of Respondents according to Prevailing Work Climate

\begin{tabular}{llcccccc}
\hline \multirow{2}{*}{ No. } & \multirow{2}{*}{ Governorate } & \multicolumn{7}{c}{ Prevailing Work Climate } \\
\cline { 3 - 8 } & & Poor & $\mathbf{\%}$ & Medium & $\mathbf{\%}$ & Good & \% \\
\hline 1 & Duhok & 3 & 2.273 & 15 & 11.364 & 13 & 9.848 \\
\hline 2 & Erbil & 6 & 4.545 & 18 & 13.636 & 24 & 18.182 \\
\hline 3 & Sulaimani & 4 & 3.030 & 23 & 17.424 & 26 & 19.697 \\
\hline & Total & 13 & 9.848 & 56 & 42.424 & 63 & 47.727 \\
\hline & & & $r=-0.072$ & &
\end{tabular}

This result agrees with the studies of Al-Khatteeb \& Fareed (1989) and Abdel-Aal et al. (2008).

\section{7- Prevailing Work Climate}

Table 9 shows that the percentage of respondents who referred to the prevailing work climate as poor is( $9.848 \%$ ), medium $(42.424 \%)$, and good $(47.727 \%)$ of the total respondents. It follows from the same table that the majority of respondents indicated the prevailing atmosphere was poor or medium $(52.2 \%)$. It requires taking action to improve the working conditions of the Forestry and Rangelands staff in the KR of Iraq, where individuals' performance gets affected by the work ambience and facilities available to them for performing the job (Al-Doski, 2007).

To find the relationship between the degree of respondents training needs and Work Climate variable, the Simple Correlation Coefficient was used, with a value of $(-0.072)$, which is not a significant value. Namely, there is no correlation between the two variables, which implies that the null hypothesis had been proven true. possibly because the majority of respondents feel that the prevailing work climate is not good. This result tallies with Al-Doski's (2007) study.

\section{8-Nature of Work}

Table 10 shows that the respondents who are assigned administrative jobs account for (21.212\%), while those who are not charged with administrative work are $(78.788 \%)$ of all the respondents. This means that the majority of respondents have full-time field work, which is a good indicator as delegating administrative tasks to the personnel wastes a large part of their time at the expense of their primary career.

To find the correlation between the degree of staff training needs and Nature of Work variable, Chi-square was used, with a significant value of (1.393). That is to say, there is no correlation between the two variables, which implies that the null hypothesis had been proven true, possibly because the majority of the administrative or non-administrative respondents belong to the Shorttenured category. This result agrees with the studies of Al-Ma'moori (1995) and Al-Abassi (1998).

\section{Workplace}

As shown in Table 11, (6.061\%) of the respondents work in villages, (31.061\%) of them work in Subdistricts, (28.030\%) in District centers, and (34.848\%) in Provincial centers.

To find the relationship between the degree of staff training needs and Workplace variable, Chi-square was used, with an insignificant value of (3.606). That is, there is no correlation between the two variables, which implies that the null hypothesis had been proven true, perhaps because a few of the respondents work in villages. This result does not agree with Al-Abassi's (1998) study.

\section{Participation in Training}

As seen from Table 12 that the respondents who participated in training are $(28.03 \%)$ and the respondents who did not participate $(71.970 \%)$. It means that the majority of respondents did not participate in any training, which reflects a clear deficiency in the number of trainings provided for the 
Forestry and Rangelands staff in the KR. Besides, the vast majority of them are not foresters and nor groomed at all to work in Forestry.

Table 10. Shows Distribution of Respondents according to Nature of Work

\begin{tabular}{|c|c|c|c|c|c|c|}
\hline \multirow[t]{2}{*}{ No. } & \multirow[b]{2}{*}{ Governorate } & \multicolumn{4}{|c|}{ Nature of Work } & \multirow{2}{*}{$\chi^{2}$} \\
\hline & & $\begin{array}{c}\text { Administrative } \\
\text { Officer }\end{array}$ & $\%$ & $\begin{array}{c}\text { Field } \\
\text { Officer }\end{array}$ & $\%$ & \\
\hline 1 & Duhok & 10 & 7.576 & 21 & 15.909 & \multirow{4}{*}{1.393} \\
\hline 2 & Erbil & 6 & 4.545 & 42 & 31.818 & \\
\hline 3 & Sulaimani & 12 & 9.091 & 41 & 31.061 & \\
\hline & Total & 28 & 21.212 & 104 & 78.788 & \\
\hline
\end{tabular}

Table 11. Shows Distribution of Respondents according to Workplace

\begin{tabular}{cccccccccc} 
No & Governorat & \multicolumn{8}{c}{ Workplace } \\
\cline { 2 - 11 } • & $\mathbf{e}$ & Village & $\mathbf{\%}$ & Subdistrict & $\mathbf{\%}$ & District & $\mathbf{\%}$ & Provincial Centre & \% \\
\hline 1 & Duhok & 1 & 0.758 & 15 & 11.364 & 13 & 9.848 & 2 & 1.515 \\
\hline 2 & Erbil & 6 & 4.545 & 12 & 9.091 & 12 & 9.091 & 18 & 13.636 \\
\hline 3 & Sulaimani & 1 & 0.758 & 14 & 10.606 & 12 & 9.091 & 26 & 19.697 \\
\hline & Total & 8 & 6.061 & 41 & 31.061 & 37 & 28.03 & 46 & 34.848 \\
\hline & $\chi$ & & & & & 3.606 & & & \\
\hline
\end{tabular}

Table 12. Distribution of Respondents according to Participation in Training

\begin{tabular}{llcccc}
\hline \multirow{2}{*}{ No. } & \multirow{2}{*}{ Governorate } & \multicolumn{4}{c}{ Participation in Training } \\
\cline { 3 - 6 } & & Participated & $\mathbf{\%}$ & Did not Participate & \% \\
\hline 1 & Duhok & 16 & 12.121 & 15 & 11.364 \\
\hline 2 & Erbil & 12 & 9.091 & 36 & 27.273 \\
\hline 3 & Sulaimani & 9 & 6.818 & 44 & 33.333 \\
\hline Total & 37 & 28.030 & 95 & 71.970 \\
\hline \multicolumn{2}{r}{$r=0.071$}
\end{tabular}

To find the correlation between the degree of staff training needs and Participation in Training variable, the Simple Correlation Coefficient was used, with an insignificant value of (0.071). That is, there is no correlation between the two variables, which implies that the null hypothesis had been proven true, perhaps because most of the respondents did not participate in trainings although they are necessary for forest workers to enhance their work competence and skills. This result is consistent with the studies of Al-Khatteeb \& Fareed (1989) and Muhammad (2009).

\section{1-Attitudes towards Forestry Work}

As seen from Table 13, the respondents who have a negative attitudes towards Forestry work are (14.394\%), who are neutral $(43.182 \%)$, positive $(42.424 \%)$. It can be inferred from the Table results that the largest percentage of respondents belongs to the Neutral and Positive Attitudes groups.

To find the correlation between the degree of personnel training needs and Attitude towards Forestry Work variable, the Simple Correlation Coefficient was used, with an insignificant value of 0.042 . That is, there is no correlation between the two variables, which implies that the null hypothesis had been proven true, may be the reason that the majority of respondent personnel $(85.606 \%)$ are belong to the positive and neutral category of their attitude towards forestry work, This result does not agree with the study of Abdel-Aal et al. (2008).

Determining Correlation between Degree of Forestry and Rangelands Staff Training Needs in KR of Iraq in General and Independent Variables under Study.

To determine the correlation between the degree of Forestry and Rangelands personnel training needs in $\mathrm{KR}$, Iraq as a dependent variable and set of independent variables under study, the Multiple Regressions Analysis was employed. The model included the independent variables (Background, Tenure and Age) excluding the other independent variables that are not significantly related to the dependent variable. It was found that the 3 independent variables together accounted for $33.7 \%$ of the variance in the KR Forestry and Rangelands personnel training needs as in Table 14.

It can be seen from the table above that the Background variable in the first phase of the model has accounted for $(28.9 \%)$ of the variance in the dependent variable. It is followed by the Tenure variable that contributed to $(3.3 \%)$ of the variance in the dependent 
variable and then the Age variable (1.5\%). Thus the research hypothesis that states (There is no significant correlation between the Forestry and Rangelands staff training needs in the KR of Iraq as a dependent variable and the independent variables under study) is rejected and the alternative hypothesis is accepted. From this it is clear that the variable Background ranked first in significance accounting for $(28.9 \%)$ of the variance in the respondents' training needs. It can be attributed to the influence of rural background on respondents' realization of forests significance and problems. They are in proximity to their homes and hence they are keen to learn all that is new in their field of work.

Assessing Significance of Forest Protection and Development Challenges in KR of Iraq

The study results showed that the total score of Forestry and Rangelands staff perception of the problems significance ranged between (57 and 110), with arithmetic mean of (86.424) and standard deviation (11.445). The Forestry and Rangelands staff according to the degree of awareness of these problems significance into 3 categories: First, Forestry and Rangelands staff who took scores between (57 and 74) and accounted for $(15.909 \%)$ of the total respondent staff. The second category included Forestry and Rangelands staff whose values ranged from (75 to 92) and accounted for $(57.576 \%)$. The third comprised of the staff whose scores were between (93 and 110) and accounted for $(26.515 \%)$ of the overall respondents.

It is clear from Table 15 that the majority of Forestry and Rangelands respondent staff belong to the 'medium' and 'high' categories, especially in the governorates of Erbil and Sulaimani. In other words, most of the respondents believe these problems impede their ability to perform the required tasks and achieve the planned objectives. Accordingly, the people in charge of the Forestry sector should take these challenges into account and strive in collaboration with other relevant institutions to overcome them and find the most appropriate solutions to them. It is seen from the Table 16 that all the problems had the Average significance scores between (3.2) and (4.5, i.e). between 'medium' and 'high'. It implies that Forestry sector workers in the target area generally suffer from all the surveyed problems to some or great extent.

Table 13. Distribution of Respondents according to Attitude towards Forestry Work

\begin{tabular}{|c|c|c|c|c|c|c|c|}
\hline \multirow{2}{*}{$\begin{array}{c}\text { No } \\
\text { • }\end{array}$} & \multirow[b]{2}{*}{ Governorate } & \multicolumn{6}{|c|}{ Attitude towards Forestry Work } \\
\hline & & $\begin{array}{c}42 \text { or Less } \\
\text { Negative }\end{array}$ & $\%$ & $\begin{array}{c}43-52 \\
\text { Neutral }\end{array}$ & $\%$ & $\begin{array}{c}53 \text { or More } \\
\text { Positive }\end{array}$ & $\%$ \\
\hline 1 & Duhok & 3 & 2.273 & 14 & 10.606 & 14 & 10.606 \\
\hline 2 & Erbil & 8 & 6.061 & 22 & 16.667 & 18 & 13.636 \\
\hline 3 & Sulaimani & 8 & 6.061 & 21 & 15.909 & 24 & 18.182 \\
\hline & Total & 19 & 14.394 & 57 & 43.182 & 56 & 42.424 \\
\hline \multicolumn{8}{|c|}{$r=0.042$} \\
\hline
\end{tabular}

Table 14. Multiple Regressions Analysis of Relationship between Forestry and Rangelands Staff Training Needs and Independent Variables

\begin{tabular}{llccccc}
\hline $\begin{array}{c}\text { No } \\
\cdot\end{array}$ & $\begin{array}{c}\text { Independent } \\
\text { Variables }\end{array}$ & $\begin{array}{c}\text { Correlation } \\
\text { Coefficient }\end{array}$ & $\begin{array}{c}\text { Coefficient of } \\
\text { Determination R2 }\end{array}$ & $\begin{array}{c}\text { Change in } \\
\text { Coefficient of } \\
\text { Determination R2 }\end{array}$ & $\begin{array}{c}\text { Partial } \\
\text { Regressions } \\
\text { Coefficient }\end{array}$ & $\begin{array}{c}\text { F } \\
\text { Value }\end{array}$ \\
\hline 1 & Tenure & 0.182 & 0.033 & 0.033 & 0.257 & $3.13^{* *}$ \\
\hline 2 & Age & 0.22 & 0.048 & 0.015 & 4.967 & $3.94^{*}$ \\
\hline 3 & Background & 0.581 & 0.337 & 0.289 & 426.498 & $38.15^{*}$ \\
\hline
\end{tabular}

*Significant at 0.05 level

$\mathrm{Y}=-356+0.257 \mathrm{X}^{2}+4.967 \mathrm{X}^{1}+426.298 \mathrm{X}^{3}$

Table 15. Shows Distribution of Forestry and Rangelands Staff Respondents according to Awareness of Obstacles to Forest Protection and Development Work

\begin{tabular}{llcccccc}
\hline \multirow{2}{*}{ No. } & \multirow{2}{*}{ Governorate } & \multicolumn{7}{c}{ Categories } \\
\cline { 3 - 8 } & & $\mathbf{5 7 - 7 4}$ & $\mathbf{0}$ & $\mathbf{7 5 - 9 2}$ & $\mathbf{\%}$ & $\mathbf{9 3 - 1 1 0}$ & \% \\
\hline 1 & Duhok & 10 & 7.576 & 9 & 6.818 & 12 & 9.091 \\
\hline 2 & Erbil & 4 & 3.030 & 36 & 27.273 & 8 & 6.061 \\
\hline 3 & Sulaimani & 7 & 5.303 & 31 & 23.485 & 15 & 11.364 \\
\hline & Total & 21 & 15.909 & 76 & 57.576 & 35 & 26.515 \\
\hline
\end{tabular}


Table 16. Shows Average Scores of Problem Extents

\begin{tabular}{|c|c|c|c|}
\hline No & Items & $\begin{array}{c}\text { Average } \\
\text { Problem Score }\end{array}$ & $\begin{array}{c}\operatorname{Ran} \\
\mathbf{k}\end{array}$ \\
\hline 1 & Conversion of Woodlands to Others & 4.477 & 1 \\
\hline 2 & Misunderstanding Value of Forests & 4.295 & 2.5 \\
\hline 3 & Ineffectiveness of Laws and Regulations Relating to Forest Protection & 4.295 & 2.5 \\
\hline 4 & Misuse of Forests by Local residents & 4.235 & 4.5 \\
\hline 5 & $\begin{array}{l}\text { Local residents' Misunderstanding Significance and Role of Forests in Economic } \\
\text { Development }\end{array}$ & 4.235 & 4.5 \\
\hline 6 & Damage Caused by Forest Pests and Diseases & 4.182 & 6 \\
\hline 7 & Lack of Funds Allocated for Programs of Forests Development & 4.144 & 7 \\
\hline 8 & Lack of Stable Policy in Administrative and Developmental Actions & 4.129 & 8 \\
\hline 9 & Illegal Logging by Local residents & 4.114 & 9 \\
\hline 10 & Breeding Goats and Cattle in Rural Areas Near Forests & 4.076 & 10 \\
\hline 11 & Unscientific Methods to Take Advantage of Forest Products & 4.038 & 11 \\
\hline 12 & Small Number of Well-trained Staff & 3.977 & 12 \\
\hline 13 & $\begin{array}{l}\text { Forestry Departments' Lack of Independence in Making Proper Decisions for } \\
\text { Programs Planning and Implementation }\end{array}$ & 3.947 & 13 \\
\hline 14 & $\begin{array}{l}\text { Poor Coordination between Forestry Departments and Other Government } \\
\text { Institutions in Forest Protection }\end{array}$ & 3.932 & 14 \\
\hline 15 & Natural and Non-natural Fires & 3.871 & 15 \\
\hline 16 & Illiteracy among Local residents & 3.803 & 16 \\
\hline 17 & Constant Changes in Forest Policies, Laws and Programs & 3.765 & 17 \\
\hline 18 & Constructing and Opening Roads in Forests & 3.682 & 18 \\
\hline 19 & Deforestation for Building Purposes & 3.432 & 19 \\
\hline 20 & Increased Population in Rural Areas and Growing Demand for Forest Products & 3.417 & 20 \\
\hline 21 & Local residents' Growing Need for Trees as Fuel & 3.197 & 21 \\
\hline 22 & Local residents' Misuse of Farmlands and Pastures & 3.182 & 22 \\
\hline
\end{tabular}

V.great 5, Great 4, Medium 3, Small 2, None 1.

Sorting the problems and obstacles of forest protection and development according to significance, the five most significant problems and obstacles from as perceived by the Forestry and Rangelands staff respondents are: (Conversion of Woodlands to Others, Misunderstanding Value of Forests, Ineffectiveness of Laws and Regulations Relating to Forest Protection, Misuse of Forests by Local residents, Local residents' Misunderstanding Significance and Role of Forests in Economic Development). From the foregoing points, it is clear that the obstacles or problems pertaining to the education of all the social groups about the forests importance and their sustainable use come to the fore in terms of significance. That requires effective extension programmes to raise the local residents and other groups' awareness of the forests worth and how to protect them. They should be engaged in such programmes in all stages.

\section{Suggestions of Forestry and Rangelands Staff in KR of Iraq for Forest and Range Development}

It is clear from Table 29 results that the respondents' most significant suggestions for overcoming the problems and obstacles to the forest protection and development in descending order are: (Reforestation in Affected Forest Areas) where $96.97 \%$ respondents indicated as Very Significant or Significant; (Continuance of Government Support for Forests and Their Institutions) $94.697 \%$ respondents said Very Significant or Significant; (Dissemination of Information on Natural Resources Significance and Benefits, particularly among Youth and Students) 93.182\% stated as Very Significant or Significant; (Raising Awareness among Local Residents) 91.667\% noted as Very Significant or Significant, (Implementing and Following up Annual Campaigns for Cultivation of 
Forest Trees) $93.182 \%$ as Significant, Very Significant or Significant.

Table 17. Shows Suggestions of Forestry and Rangelands Staff in KR of Iraq for Forest and Range Development

\begin{tabular}{|c|c|c|c|}
\hline No. & Items & $\begin{array}{c}\text { Average } \\
\text { Significance of } \\
\text { Suggestion } \\
\end{array}$ & Rank \\
\hline 1 & Reforestation in Affected Forest Areas & 4.659 & 1 \\
\hline 2 & Continuance of Government Support for Forests and Their Institutions & 4.644 & 2 \\
\hline 3 & $\begin{array}{l}\text { Dissemination of Information on Natural Resources Significance and } \\
\text { Benefits, particularly among Youth and Students }\end{array}$ & 4.606 & 3 \\
\hline 4 & Raising Awareness among Local Residents & 4.568 & 4 \\
\hline 5 & $\begin{array}{l}\text { Implementing and Following up Annual Campaigns for Cultivation of Forest } \\
\text { Trees }\end{array}$ & 4.553 & 5 \\
\hline 6 & Providing Sufficient Fuel for Local residents Especially in Winter & 4.523 & 6 \\
\hline 7 & Regarding Forests as Nature Reserves & 4.455 & 7 \\
\hline 8 & Training Forest Guards and Building Their Capacities & 4.379 & 8 \\
\hline 9 & Forming Associations and Organizations of Forest Protection and Utilization & 4.348 & 9 \\
\hline 10 & Construction of Houses and Other Facilities Away from Forests & 4.311 & 10 \\
\hline 11 & Fencing Forests and Supplying Livestock Breeders with Fodder & 4.227 & 11 \\
\hline 12 & Not Granting Licenses for Coal Production & 4.174 & 12 \\
\hline 13 & $\begin{array}{l}\text { Designing Scientific Programmes and Actions on Livestock Husbandry for } \\
\text { Breeders }\end{array}$ & 4.061 & 13 \\
\hline
\end{tabular}

V.Significant 5 , Significant 4 , M. Significant 3 , Little Significant 2 , Insignificant 1.

\section{CONCLUSIONS}

1. The KR-Iraq Forestry and Rangelands personnel respondents are in great need of training in all the Forestry disciplines under study.

2. The respondents' need for training in Range Management is at the forefront of forestry disciplines under study, and the need for training in Agroforestry came second.

3. The items (Air Pollution by Plant Gases; Tourism Role in National Economy; Media Role in Developing Tourism; Laws and Legislations on Forest Protection; Testing and Analysing Water Samples) were the first 5 of the scale items regarding the need for training.

4. There is a significant correlation between (Age , background and tenure) and Need for Training.

5. The 3 independent variables together account for $33.7 \%$ of the variance in KR-Iraq Forestry and Rangelands personnel training needs.

\section{RECOMMENDATIONS}

1. It is imperative to focus on mass media as effective means or channels for communicating forests, components and other natural resources information to community members and urge them to act and deal with the various ecosystem components rationally as to keep their sustainability.

2. It is necessary the official and non-governmental institutions and the public make further efforts to replant the affected forest areas.

3. There is an urgent need to organize and carry out intensive information campaigns to educate citizens and tourist sightseers about the importance of forest how to deal with and protect them and properly dispose of astes. This can be done by instructing them through stickers, labels, placards, posters and other available extension means.

4. To deal seriously with the constraints and problems facing the forest conservation, protection and sustainable management, vegetation and to minimize and overcome the challenges through an integrated package of actions.

5. There is a need to find forms of cooperation and good coordination and continuous between forests institutions and various other rural development institutions consistent with or related to the objectives and avoid duplication of activities offered in the region.

6. It is essential to ensure coordination between forest departments and local media, like television, radio and newspapers to broaden the local residents' 
knowledge of the forests significance and how to use and maintain them.

7. Intensive induction trainings should be provided for new personnel so that they would acquire practical knowledge of all the required activities. Additionally, during-the-service focus trainings need to be given in accordance with the need priorities of KR-Iraq Forestry and Rangelands personnel. Planning and implementing such training programmes should be observed at a high level of efficiency to make competent cadres.

8. Training plans and programs should be developed for the KRIraq Forestry and Rangelands personnel in the priority subjects the respondents expressed their desire to be trained.

\section{REFERENCES}

Chizari,M.,S.Verma and H. Farhadian( 1999),Preceptions of forestry and range organization managers of the role of extension in protection of forest in Iran, Journal of international Agricultural and extension Education, Vol. 39, No, 1 .

Faham,E., A.rezvanfar and T.shamekhi(2008), Analysis of socio-Economic factors influencig forest dwellers' participation in reforestation and development of forest area (the case study of west Mazandran, Iran), American journal of Agricultural and biological science,Vol.3,No.1.

FAO(2009), State of world's forestry, Rome.

الغطيب، حورية كلمل ومحمد لحمد فريد(1919)، دارسة في تقير الاحتيلجلت التدريبية للمششين الزراعين بمحلفة

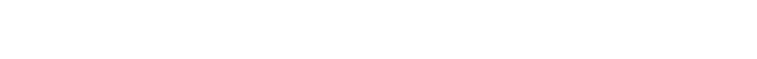

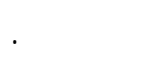

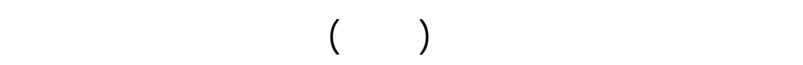
الإبشادية للمرلكز الإششادية الزراعية في محلفلت دهوك

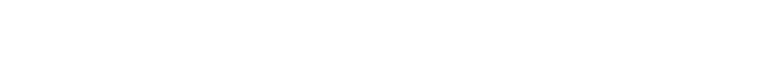

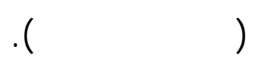

الثدايدة، لحمد نوري مسن(1999)، الاحتيلجك التدريبية

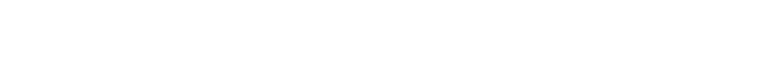
كلية الزراعة، جلمعة بغداد، (طروحة لكتورله).

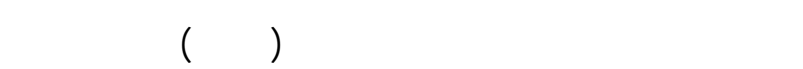
المعرفية للموظفين الزراعيين في محلظة نينوى في مجالات

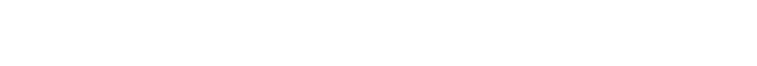
(سالة ملجستير).
العبلي،، علل فلضل خليل(1991)، درلسة الاحتيلجلت الموظفن الزراعين في محلظة نيذوى لبعض المعارف والخبرك الإششاصية الزراعية، جلمعة الموصل، كلية

$$
\text { الزراعة والغابت، (لطروحة كتورل). }
$$

العبلهي، علمل فاضل خليل، عابد علي هسن وزهراء ميسر البصو(ع - . r)، الاحتيلجت العلملين بالإبشاد الزراعي في محلظتي دهوك واربيل لبعض المعارف والخبرات الإشادية

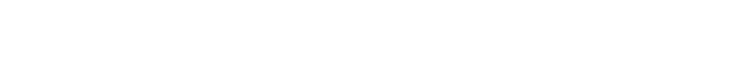

$$
\text { دهوك، مجلدV، العددr. }
$$

العبلي،علمل فاضل خليل، عابد علي هنن وضوية لحمد إبراهيم(0 . r)، لستخده طريقة بوريك المطورة في فقير

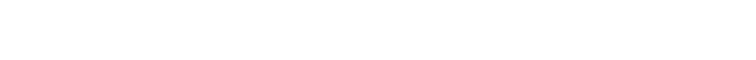
الإشاد للعلملن بالإششاد الزراعي في محافظتي دهوك واربيل، مجلة جلمعة دهوك، المجلدی، العدد ا. . عبدالعل، محمدهن، خيري هسن أبوللسعود، سيلثرف

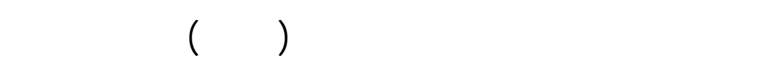
التدريبية للمششين الزراعين في مجل المكافحة الحيوية

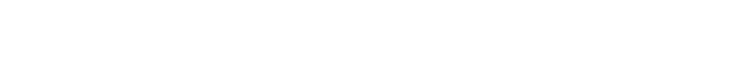
.J.Agric.Sci.Mansoura Univ.

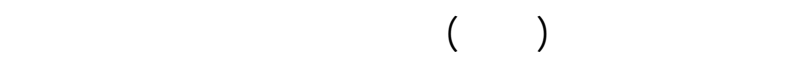
والغابت، جلمعة الموصل.

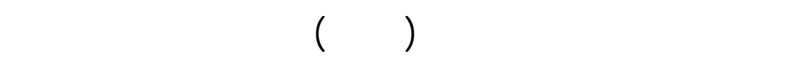
لمزارعي ناحية العبلسي بمحلظة كركوك في مجل لستخدلم

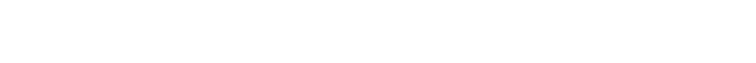

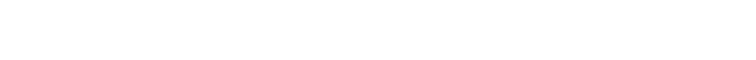

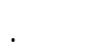

غضيب، علي لحمد، دعاء ضياء مسين(با. r)، الحلجلت التدريبية لزراع الحظة المروية في قضاء بيجي وعلاقتها ببعض المتغيرات مجلة جلمعة تكريت للعلو الزراعية،

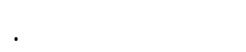


المعموري، صباح حبيب مزهر(990)، درلسة الاحتيلجل محمد، محمد عمر(9. ب)، الحلجلت التدريبية الإشادية

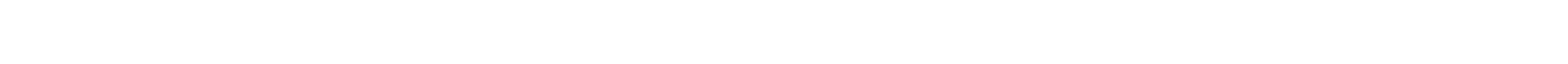

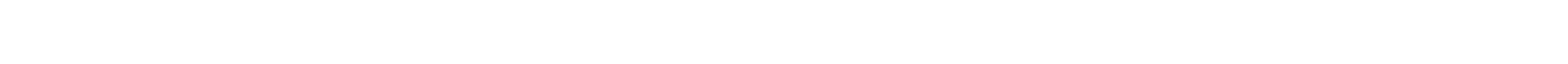

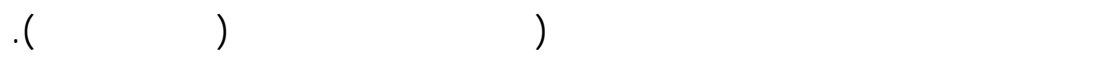
غير منشورة). 


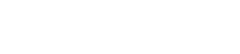

\section{الحتياجلت الثرببية المظفي الغلبك والمراعي في لفليمكرصتل العرق وعلافها ببهن المتغيرات الشخصية والظليفية}

عابد علي عسن الدوسكي، مزة بهزاد محمد للسنايي

النكرارات، المتوطلت، النسب المئوية، تحليل الانحدار

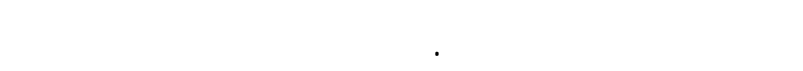
عنها الدرلسة تبتمل في الاتي:

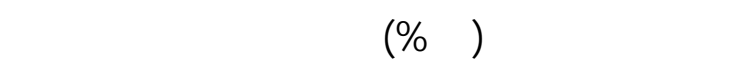

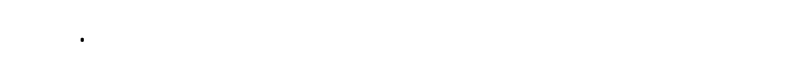
الحلجة إلى التدريب في مجل إدارة المراعي جاعت في الماتي

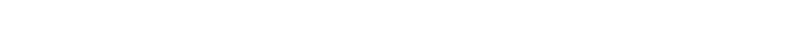
وجاءت الحلجة إلى التدريب في مجل الزراعة المختلطة

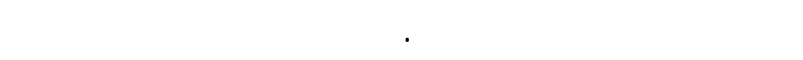
علاقة ارتبطية معنوية بين الحلجة إلى التدريب ولمل من التهن المتغيرات المسقلة (العمر، الخمة الوظفية، الشأة). ولن الن

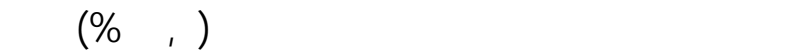
التباين في الاحتيلجلت التدريبية لموظفي الغابلت والمراعي في قليم كرهستان العراق. وفي ضوء النتائج التي مم التوصل اليها، قم البهث مجموعة من التوصيك الهمها إجراء دورات تدريبية

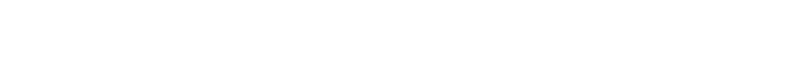
الغابلت والمراعي في إقليم كرستان العراق مع مراعة العالة تخطيط وتفيذ هذه البرلمج التدريبية على مستوى رفيع من

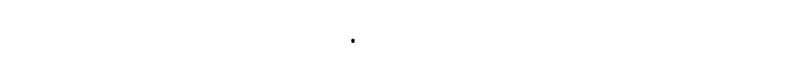
تدريبية لموظفي الغابت والمراعي في إقليم كرهستان في الغان الموضوعت ذات الأولوية والني أببى المبحوثنين الرغبة المبنة

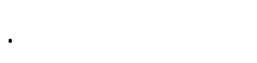

إن حماية الغابلت من التحديت وعوامل التدهور المختلفة والعل على زيادة مسلحاتها بحلجة إلى إشاداد مكف على جميع المستويت والثررائح الاجتماعية للتوعية

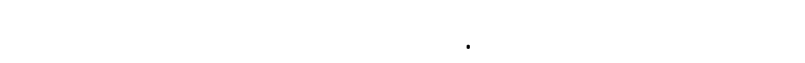
فعالة ومتكلملة هي وجود كوادر كفؤة ومؤهلة ومتدربة جيدا وقادرة على إيصل الرسالة الإيشادية وتوعية اللسكان

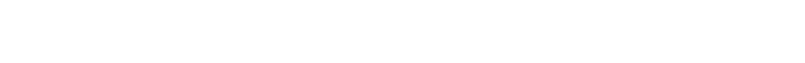
البرامج وفي جمبع بمرلحلها. ويهوف هذا البحث لملسا اله ققدير الاحتيلجلت التدريبية

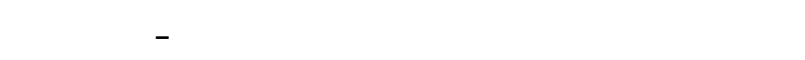

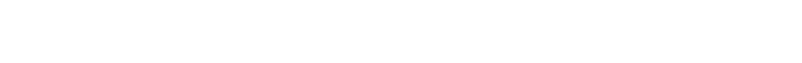

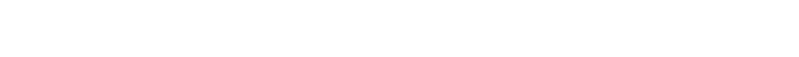
التدريبية وبعض الخصائص اللخخصية والوظفية. وتحديد

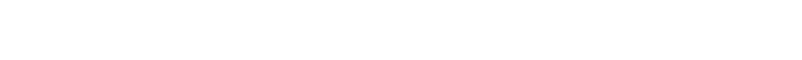

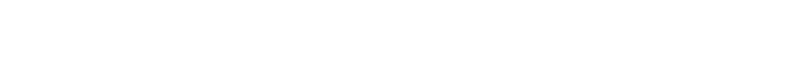
لطوير وتحسين الغابلت في اقليم كرهستن العراق. وشملت

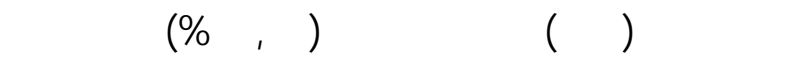

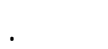

وقم جمع بيانت البحث من خلال لستمارة المستبيلن

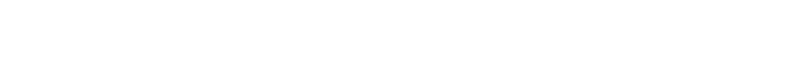
محتواها مت قيلس ثبات المقيلس (الاهمية، المعلومات،

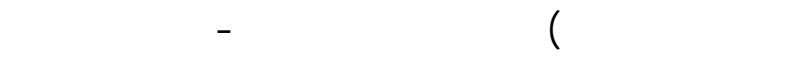
فريغ البيانت وتصنفها تمت معالجتها لحصائيا بلستخدلم

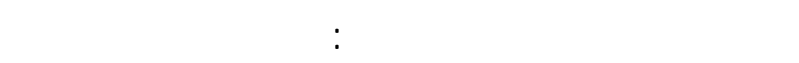

